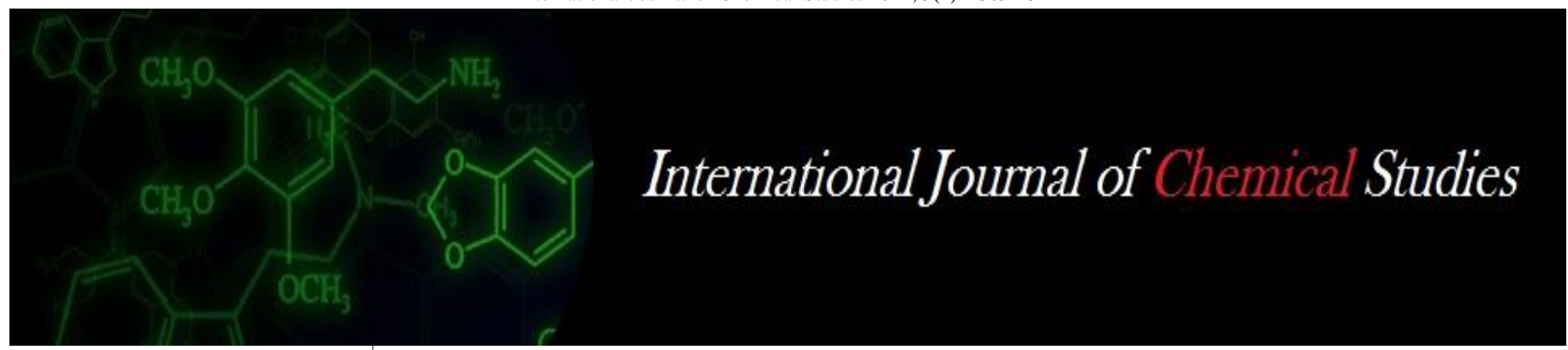

P-ISSN: 2349-8528

E-ISSN: 2321-4902

www.chemijournal.com

IJCS 2021; 9(1): 1309-1312

(C) 2021 IJCS

Received: 02-10-2020

Accepted: 09-11-2020

Bharathalakshmi M

Acharya N.G. Ranga

Agricultural University, Guntur,

Andhra Pradesh, India

Gouri V

Acharya N.G. Ranga

Agricultural University, Guntur,

Andhra Pradesh, India

Sitaramalakshmi CH

Acharya N.G. Ranga

Agricultural University, Guntur,

Andhra Pradesh, India

Kumari MBGS

Acharya N.G. Ranga

Agricultural University, Guntur,

Andhra Pradesh, India

Chitakal Devi T

Acharya N.G. Ranga

Agricultural University, Guntur,

Andhra Pradesh, India

Ramanamurthy KV

Acharya N.G. Ranga

Agricultural University, Guntur,

Andhra Pradesh, India

\section{Impact of micronutrient supplementation through drip fertigation on growth, yield and recovery in sugarcane}

\author{
Bharathalakshmi M, Gouri V, Sitaramalakshmi CH, Kumari MBGS, \\ Chitakal Devi T and Ramanamurthy KV
}

DOI: https://doi.org/10.22271/chemi.2021.v9.i1s.11402

\begin{abstract}
Sugarcane is an important commercial crop grown in Andhra Pradesh in an area of 1.0 lakh ha. It is a high biomass producing crop and depletes large quantities of nutrients from soil. A sugarcane crop producing 100tons of cane ha $^{-1}$ remove $208 \mathrm{Kg} \mathrm{N}, 53 \mathrm{Kg} \mathrm{P}, 280 \mathrm{Kg} \mathrm{K}, 30 \mathrm{Kg} \mathrm{Fe}, 1.2 \mathrm{Kg} \mathrm{Mn}, 0.6 \mathrm{Kg} \mathrm{Zn}$ and $0.2 \mathrm{Kg} \mathrm{Cu}$ respectively from soil. Considering the need of micro nutrients for productively enhancement in sugarcane, a field study was carried out at Regional Agricultural Research Station, Anakapalle, North Coastal Andhra Pradesh for 3 consecutive years from 2016-17 to 2018-19 to know the impact of different micro nutrients supply through soil and fertigation along with supply of major nutrients of NPK. The experimental results indicated that application of $\mathrm{Zn} @ 25 \mathrm{Kg} / \mathrm{ha}$ through drip fertigation or application of combination of micro nutrients as Formula-4 @2 Kg ha ${ }^{-1}$ in 10 splits at weekly interval commencing from 45 days after planting to 180 days after planting favoured good growth and culminated in higher cane yield, sugar yields and uptake of macro and micro nutrients.
\end{abstract}

Key words: Fertigation, macro nutrients, nutrient uptake, stripped cane yield

\section{Introduction}

Sugarcane is a high biomass producing crop in the world and depletes huge amount of nutrients from soil. On an average, a sugarcane crop producing 100 tons of cane ha ${ }^{-1}$ removes $208 \mathrm{~kg} \mathrm{~N}, 53 \mathrm{Kg} \mathrm{P}, 280 \mathrm{~kg} \mathrm{~K}, 30 \mathrm{Kg} \mathrm{S}, 3.4 \mathrm{Kg} \mathrm{Fe}, 1.2 \mathrm{Kg} \mathrm{Mn}, 0.6 \mathrm{Kg} \mathrm{Zn}$ and $0.2 \mathrm{Kg} \mathrm{Cu}$ respectively from the soil. Sugarcane crop removes substantial amount of plant nutrients from the soil and use of NPK fertilizers alone cannot maintain higher yields in long run because of emergence of secondary and micronutrient deficiencies and deterioration of soil physical properties. Therefore, it is very much essential to replenish the depleted nutrients both macro and micro nutrients to enhance the cane productivity and maintain soil quality.

Micronutrient deficiency is one of the factors limiting sugarcane yield around the world mainly due to use of fertilizers with low levels of micronutrients, decreased levels of organic matter, increased cultivation in areas with low soil fertility, reduced application of organic residues in cultivated areas. Micronutrients are of immense significance though the plants require in small quantities as these micronutrients play crucial role in growth, development, yield and quality of produce. The deficiency of any nutrient may result in growth retardation and low yields as the deficient nutrient minimizes the usefulness of other agricultural inputs including NPK fertilizers (Punhwar et al., 2003) ${ }^{[5]}$. Shafique mazhar (2016) ${ }^{[6]}$ reported that Zinc and Boron@ 7.0 and $1.5 \mathrm{~kg} \mathrm{ha}^{-1}$ respectively was optimum for realising economically higher cane yield and recovery. Application of micronutrients like $\mathrm{Zn}$ and $\mathrm{Fe}$ in addition to NPK fertilizers is necessary to realize maximum benefits from sugarcane crop.

The dose and time of application of major nutrients under drip fertigation for sugarcane crop has been standardized but response to micro nutrient supply through drip fertigation was not studied and felt essential as fertigation improves the nutrient use efficiency besides saving irrigation water and increase the cane yield. Micronurtient use in sugarcane is a recent practice and not much work has been carried out for wide spread application. Hence, a study was planned and executed to assess the impact of micronutrients supplied through soil and fertigation in drip irrigated sugarcane.
Corresponding Author: Bharathalakshmi M

Acharya N.G. Ranga Agricultural University, Guntur, Andhra Pradesh, India 


\section{Materials and Methods}

A field study was conducted at Regional Agricultural Research Station, Anakapalle for 3 consecutive seasons from 2016-17 to 2018-19 on a sandy loam soil. The experimental soil was neutral in $\mathrm{pH}(7.96)$ low in E.C $\left(0.18 \mathrm{ds} / \mathrm{m}^{2}\right)$ organic carbon $(0.65)$, available nitrogen $(234 \mathrm{~kg} / \mathrm{ha})$ high in available $\mathrm{P}_{2} \mathrm{O}_{5}(70 \mathrm{~kg} / \mathrm{ha})$, medium in available potassium $(177 \mathrm{~kg} / \mathrm{ha})$, and sufficient in $\mathrm{Zn}(0.98 \mathrm{ppm})$ and $\mathrm{Fe}$ (13.1 ppm). The experiment was laid out in a randomized block design with 3 replications and treatments consisted of application of micronutrients viz., $\mathrm{Zn}, \mathrm{Fe}, \mathrm{B}$ and micronutrient mixture in the form formula 4 through soil and drip fertigation tested along with control (No micronutrient application). Micronutrients were applied to soil at 45 DAP as per treatments while in drip fertigation, micro nutrients as per treatments were applied through irrigation water with the help of ventury system commencing from 45 DAP to 120 DAP in 10 equal splits. Nitrogen@112 kg /ha was supplied in the form of urea in 20 splits at weekly interval commencing from 30 DAP to 180 DAP while phosphorus @ 100 kg $\mathrm{P}_{2} \mathrm{O}_{5} \mathrm{ha}^{-1}$ and potassium @ $120 \mathrm{~kg} \mathrm{ha}^{-1}$ were applied in planting furrows in the form of single super phosphate and muriate of potash. All other agronomic practices like weeding, earthing up, T.T. propping etc. and plant protection measures against early shoot borer, top rot, wooly aphid etc., were done as per recommendation to North Coastal Andhra Pradesh. An early maturing clone 2000A 56 was used as test variety. During crop growth period. Data on germination of setts, shoot population at 180 days after planting (DAP) were recorded. The crop was harvested at peak maturity and data on length of millable canes, average girth and stripped cane yield were recorded at harvest. Before harvesting cane samples were drawn from each treatment (10 canes/plot), canes were crushed. Juice was extracted and tested for quality parameters like Brix, juice sucrose, purity and CCS\% was calculated based on brix and sucrose. Plant samples were collected at the end of grand growth and analysed for major and micro nutrients content and uptake of macro and micro nutrients was calculated based on cane yield and nutrient content. The data was analysed statistically as suggested by Panse and Sukhatme (1986) to draw conclusion.

\section{Results and Discussion}

The data on germination of setts (\%), stalk population at 180 days after planting (DAP), average length and girth of millable canes, number of internodes/millable cane, number of millable cane population at harvest, cane and sugar yields, quality parameters viz., brix \%, sucrose and $\mathrm{CCS} \%$ and nutrient uptake at grand growth stage are presented in tables 1 to 6.

\section{Growth parameters \\ Germination of setts}

A perusal of the data presented in table 1 on germination of setts recorded at 35 DAP indicated that germination did not vary among the treatments as treatments were imposed at 45 DAP. Germination of setts ranged from 70.3 to 78.6 among the treatments.

Table 1: Influence of micronutrient application through drip fertigation on germination and shoot population

\begin{tabular}{|c|c|c|c|c|c|c|c|c|}
\hline \multirow[b]{2}{*}{ Treatment } & \multicolumn{4}{|c|}{ Germination (\%) } & \multicolumn{4}{|c|}{ Shoot population at 180 DAP } \\
\hline & $\begin{array}{c}2016- \\
17\end{array}$ & \begin{tabular}{|c|}
$2017-$ \\
18
\end{tabular} & \begin{tabular}{|c|}
$2018-$ \\
19
\end{tabular} & Mean & $\begin{array}{c}\text { 2016- } \\
17\end{array}$ & $\begin{array}{c}2017- \\
18\end{array}$ & $\begin{array}{c}\text { 2018- } \\
19\end{array}$ & Mean \\
\hline T1- Control & 83.6 & 72.7 & 78.6 & 78.3 & 156667 & 100205 & 105555 & 120809 \\
\hline T2- Soil application of ZnSo4 @ $50 \mathrm{Kg} / \mathrm{ha}$ & 82.0 & 74.5 & 70.3 & 75.6 & 156667 & 96707 & 106179 & 119851 \\
\hline T3- Application of ZnSo4 @ $25 \mathrm{Kg} / \mathrm{ha}$ through drip & 84.8 & 68.2 & 71.7 & 74.9 & 163056 & 102880 & 110590 & 125509 \\
\hline T4-Soil application of FeSo4 @ $50 \mathrm{Kg} / \mathrm{ha}$ & 83.6 & 73.1 & 79.5 & 78.7 & 160833 & 102057 & 109201 & 124030 \\
\hline T5-Application of FeSo4@ $25 \mathrm{Kg} / \mathrm{ha}$ through drip & 87.9 & 69.2 & 73.1 & 76.7 & 167500 & 98765 & 111284 & 125850 \\
\hline T6-Soil application of B @ $1 \mathrm{Kg} / \mathrm{ha}$ & 89.8 & 69.4 & 74.0 & 77.7 & 170833 & 102674 & 111110 & 128206 \\
\hline T7-Application of B @ $0.5 \mathrm{Kg} / \mathrm{ha}$ through drip & 81.6 & 72.1 & 70.5 & 74.7 & 160000 & 101645 & 111631 & 124425 \\
\hline T8- Soil application of combination of micro nutrientsas formula-4 @ $4.0 \mathrm{~kg} / \mathrm{ha}$ & 83.3 & 69.2 & 70.7 & 74.4 & 159722 & 102057 & 107465 & 123081 \\
\hline T9- Application of combination of micro nutrients as formula -4 @ 2 kg/ha & 83.0 & 69.2 & 78.6 & 76.9 & 158056 & 89506 & 113888 & 120483 \\
\hline $\mathrm{CD}(0.05)$ & NS & NS & NS & & NS & NS & NS & \\
\hline
\end{tabular}

\section{Shoot population at 180 days after planting}

Shoot population recorded at 180 DAP did not differ significantly due to micro nutrient application and all the treatments registered more or less equal shoot population. However, application of micronutrients through drip recorded relatively higher shoot population than soil application. Among the treatments, application of micronutrient mixture in the form of Formula 4 recorded relatively higher shoot population (113888/ha) than control (105555/ha) as evident from pooled mean data in table 1 .

\section{Yield attributes}

The data on yield attributing characters viz., length of millable cane, average girth and number of internodes / millable cane are furnished in table 2 . The yield attributes viz. length and girth of millable canes and internodes / millable stalk were not influenced by micro nutrient application either through soil or through drip fertigation. The mean length of millable cane, average girth and number of internodes ranged from 288.4 (T6) to 299.7 (T9), 2.24 (T1) to 2.45 (T3) and 23.43 (T6) to 24.53 (T3) among the treatments. Jamro et al., (2002) [3] observed increase in all the growth triats of sugarcane with the application of micronutrients. Nagamadhuri et al. (2013) observed significant influence of Zinc and iron and nonsignificant effect of Boron on growth traits of sugarcane.

The number of millable canes at harvest differed significantly among the treatments during 2016-17 and 2017-18. The mean data of NMC/ha recorded with iron (79412 ha-1), Zinc (7709 $\mathrm{ha}^{-1}$ ) through drip fertigation or micronutrient mixture as Formula $4\left(75113 \mathrm{ha}^{-1}\right)$ were higher than with soil application or with NPK alone (70153 ha-1). 
Table 2: Yield attributes and yield of sugarcane as influenced by micro nutrient application

\begin{tabular}{|c|c|c|c|c|c|c|c|c|c|c|c|c|}
\hline \multirow[b]{2}{*}{ Treatment } & \multicolumn{4}{|c|}{ LMC (cm) } & \multicolumn{4}{|c|}{ Girth $(\mathrm{cm})$} & \multicolumn{4}{|c|}{ No. of internodes } \\
\hline & $\begin{array}{c}2016- \\
17\end{array}$ & $\begin{array}{c}2017- \\
18\end{array}$ & $\begin{array}{c}2018- \\
19\end{array}$ & Mean & $\begin{array}{c}2016- \\
17\end{array}$ & \begin{tabular}{|c|}
$2017-$ \\
18
\end{tabular} & $\begin{array}{c}2018- \\
19\end{array}$ & Mean & $\begin{array}{c}2016- \\
17\end{array}$ & $\begin{array}{c}2017- \\
18\end{array}$ & $\begin{array}{c}2018- \\
19\end{array}$ & Mean \\
\hline T1- Control & 348.5 & 268.0 & 269.2 & 295.2 & 2.21 & 2.27 & 2.24 & 2.24 & 28.3 & 22.8 & 20.9 & 24.00 \\
\hline T2- Soil application of ZnSo4 @ $50 \mathrm{Kg} / \mathrm{ha}$ & 356.3 & 248.2 & 286.8 & 297.1 & 2.27 & 2.38 & 2.41 & 2.35 & 28.6 & 21.6 & 22.5 & 24.23 \\
\hline T3- Application of ZnSo4 @ 25 Kg/ha through drip & 351.5 & 265.5 & 286.2 & 301.1 & 2.28 & 2.55 & 2.53 & 2.45 & 29.0 & 21.6 & 23.0 & 24.53 \\
\hline T4-Soil application of FeSo4 @ 50 Kg/ha & 342.3 & 251.8 & 287.7 & 293.9 & 2.20 & 2.36 & 2.37 & 2.31 & 29.3 & 21.0 & 22.4 & 24.23 \\
\hline T5-Application of FeSo4@ $25 \mathrm{Kg} / \mathrm{ha}$ through drip & 343.7 & 238.0 & 307.7 & 296.5 & 2.12 & 2.41 & 2.38 & 2.30 & 28.5 & 20.7 & 22.5 & 23.90 \\
\hline T6-Soil application of B @ 1 Kg/ha & 336.3 & 250.6 & 278.2 & 288.4 & 2.23 & 2.26 & 2.41 & 2.30 & 28.0 & 21.5 & 20.8 & 23.43 \\
\hline T7-Application of B @ $0.5 \mathrm{Kg} / \mathrm{ha}$ through drip & 333.5 & 264.5 & 295.0 & 297.7 & 2.26 & 2.25 & 2.45 & 2.32 & 28.7 & 21.1 & 22.8 & 24.20 \\
\hline $\begin{array}{l}\text { T8- Soil application of combination of micro nutrients as } \\
\text { formula-4@ } 4.0 \mathrm{~kg} / \mathrm{ha}\end{array}$ & 334.8 & 265.2 & 280.2 & 293.4 & 2.24 & 2.47 & 2.28 & 2.33 & 27.8 & 20.5 & 22.7 & 23.67 \\
\hline $\begin{array}{c}\text { T9- Application of combination of micro nutrients as } \\
\text { formula }-4 @ 2 \mathrm{~kg} / \mathrm{ha}\end{array}$ & 354.7 & 250.3 & 294.2 & $299.7 \mid$ & 2.29 & 2.19 & 2.28 & 2.25 & 28.7 & 21.0 & 21.7 & 23.80 \\
\hline $\mathrm{CD}(0.05)$ & NS & NS & NS & & NS & 0.13 & NS & & NS & NS & NS & \\
\hline
\end{tabular}

Table 3: Quality parameters as influenced by micronutrient application through drip fertigation

\begin{tabular}{|c|c|c|c|c|c|c|c|c|c|c|c|c|}
\hline \multirow[b]{2}{*}{ Treatment } & \multicolumn{4}{|c|}{ Brix (\%) } & \multicolumn{4}{|c|}{ Sucrose (\%) } & \multicolumn{4}{|c|}{$\operatorname{CCS}(\%)$} \\
\hline & \begin{tabular}{|c|}
$2016-$ \\
17
\end{tabular} & $\begin{array}{c}2017- \\
18\end{array}$ & $\begin{array}{c}2018- \\
19\end{array}$ & Mean & $\begin{array}{c}2016- \\
17\end{array}$ & $\begin{array}{c}2017- \\
18\end{array}$ & $\begin{array}{c}2018- \\
19\end{array}$ & Mean & $\begin{array}{c}2016- \\
17\end{array}$ & $\begin{array}{c}2017- \\
18\end{array}$ & $\begin{array}{c}2018- \\
19\end{array}$ & Mean \\
\hline T1- Control & 20.98 & 20.06 & 21.28 & 20.7 & 18.90 & 19.33 & 19.17 & $\mid 19.1$ & 13.60 & 14.28 & 13.74 & 13.9 \\
\hline T2- Soil application of ZnSo4 @ 50 Kg/ha & 21.02 & 19.49 & 20.13 & 20.2 & 18.90 & 18.29 & 18.91 & 18.7 & 13.60 & 13.36 & 13.82 & 13.6 \\
\hline T3- Application of ZnSo4 @ $25 \mathrm{Kg} / \mathrm{ha}$ through drip & 22.24 & 20.09 & 20.96 & 21.1 & 20.60 & 19.29 & 19.44 & 19.8 & 14.90 & 14.23 & 14.13 & 14.4 \\
\hline T4-Soil application of FeSo4 @ 50 Kg/ha & 20.32 & 19.41 & 20.71 & 20.1 & 18.20 & 17.37 & 19.27 & 18.3 & 13.00 & 12.42 & 14.02 & 13.1 \\
\hline T5-Application of FeSo4@ $25 \mathrm{Kg} / \mathrm{ha}$ through drip & 20.56 & 19.94 & 20.46 & 20.3 & 18.60 & 19.11 & 18.51 & 18.7 & 13.30 & 14.08 & 13.30 & 13.6 \\
\hline T6-Soil application of B @ $1 \mathrm{Kg} / \mathrm{ha}$ & 19.97 & 19.65 & 20.44 & 20.0 & 17.90 & 18.53 & 18.51 & 18.3 & 12.80 & 13.57 & 13.30 & 13.2 \\
\hline T7-Application of B @ $0.5 \mathrm{Kg} / \mathrm{ha}$ through drip & 20.44 & 18.86 & 20.37 & 19.8 & 18.40 & 16.98 & 18.63 & 18.0 & 13.10 & 12.17 & 13.45 & 12.9 \\
\hline $\begin{array}{l}\text { T8- Soil application of combination of micro nutrients as } \\
\text { formula-4 @ } 4.0 \mathrm{~kg} / \mathrm{ha} \\
\end{array}$ & 19.77 & 19.40 & 20.88 & 20.0 & 17.70 & 18.57 & 19.36 & 18.5 & 12.70 & 13.68 & 14.06 & 13.5 \\
\hline $\begin{array}{l}\text { T9- Application of combination of micro nutrients as } \\
\text { formula }-4 @ 2 \mathrm{~kg} / \mathrm{ha}\end{array}$ & 20.98 & 18.83 & 19.98 & 19.9 & 19.20 & 17.34 & 18.38 & 18.3 & 13.80 & 11.50 & 13.30 & 12.9 \\
\hline $\mathrm{CD}(0.05)$ & NS & NS & NS & & NS & NS & NS & & NS & NS & NS & \\
\hline
\end{tabular}

\section{Yield}

Stripped cane yield was significantly influenced by micronutrient application during 2016-17 and 2017-18 while in 2018-19 such significant differences were not observed (Table 4).

During 2016-17 highest cane yield was recorded with the application of combination of micronutrients in the form of Formula $4\left(117.0 \mathrm{ha}^{-1}\right)$ which was on par with application of $\mathrm{ZnSo}_{4} @ 25 \mathrm{~kg} / \mathrm{ha}\left(116.6 \mathrm{tha}^{-1}\right)$ or $\mathrm{FeSO}_{4} @ 25 \mathrm{~kg} / \mathrm{ha}$ through drip fertigation $\left(116.4\right.$ tha $\left.^{-1}\right)$ and soil application of micronutrient mixture as Formula 4@ $4.0 \mathrm{~kg} / \mathrm{ha}\left(115.7 \mathrm{ha}^{-1}\right)$ and all were found significantly superior over control (101.8 $\mathrm{ha}^{-1}$ ). In 2017-18 application of $\mathrm{FeSo}_{4}$ @ $50 \mathrm{~kg} / \mathrm{ha}$ through soil $\left(87.0 \mathrm{ha}^{-1}\right)$ or through fertigation $\left(83.7 \mathrm{ha}^{-1}\right)$ recorded significantly higher cane yield than control $\left(67.8 \mathrm{ha}^{-1}\right)$. During 2018-19 though the cane yield was not influenced by micronutrient application, highest cane yield of 94.4 tha $^{-1}$ was recorded with the application of micro nutrient mixture as Formula 4 through drip fertigation when compared to control $\left(83.5 \mathrm{ha}^{-1}\right)$.

Table 4: Yield attributes and yield as influenced by micro nutrient application through drip fertigation in sugarcane

\begin{tabular}{|c|c|c|c|c|c|c|c|c|c|c|c|c|}
\hline \multirow[b]{2}{*}{ Treatment } & \multicolumn{4}{|c|}{ NMC / ha } & \multicolumn{4}{|c|}{ Cane yield (t/ha) } & \multicolumn{4}{|c|}{ Sugar yield (t/ha) } \\
\hline & $\begin{array}{c}\text { 2016- } \\
17\end{array}$ & $\begin{array}{l}2017- \\
18\end{array}$ & $\begin{array}{c}2018- \\
19\end{array}$ & Mean & $\begin{array}{c}2016- \\
17\end{array}$ & $\begin{array}{c}2017- \\
18\end{array}$ & 2018- & Mean & $\begin{array}{c}2016- \\
17\end{array}$ & $\begin{array}{c}2017- \\
18\end{array}$ & $\begin{array}{c}2018- \\
19\end{array}$ & Mean \\
\hline T1- Control & 77655 & 64403 & 68402 & 70153 & 101.8 & 67.8 & 83.5 & 84.4 & 13.8 & 9.7 & 11.5 & 11.67 \\
\hline T2- Soil application of ZnSo4 @ 50 Kg/ha & 78097 & 65843 & 72916 & 72285 & 108.1 & 71.1 & 91.7 & 90.3 & 14.7 & 9.5 & 12.7 & 12.30 \\
\hline T3- Application of ZnSo4 @ $25 \mathrm{Kg} / \mathrm{ha}$ through drip & 82300 & 74074 & 74652 & 77009 & 116.6 & 73.0 & 93.1 & 94.2 & 17.3 & 10.4 & 13.2 & 13.63 \\
\hline T4-Soil application of FeSo4 @ $50 \mathrm{Kg} / \mathrm{ha}$ & 77655 & 84979 & 67534 & 76723 & 104.4 & 87.0 & 87.6 & 93.0 & 13.6 & 10.8 & 12.3 & 12.23 \\
\hline T5-Application of FeSo4@ $25 \mathrm{Kg} / \mathrm{ha}$ through drip & 82965 & 83744 & 71527 & 79412 & 116.4 & 83.7 & 88.4 & 96.2 & 15.5 & 11.8 & 11.8 & 13.03 \\
\hline T6-Soil application of B @ $1 \mathrm{Kg} / \mathrm{ha}$ & 82610 & 72633 & 72261 & 75835 & 110.4 & 75.7 & 88.5 & 91.5 & 14.0 & 10.3 & 11.8 & 12.03 \\
\hline T7-Application of B @ $0.5 \mathrm{Kg} / \mathrm{ha}$ through drip & 74557 & 72633 & 76041 & 74410 & 109.5 & 75.4 & 89.1 & 91.3 & 14.3 & 9.2 & 12.0 & 11.83 \\
\hline $\begin{array}{l}\text { T8- Soil application of combination of micro nutrients as } \\
\text { formula-4@ } 4.0 \mathrm{~kg} / \mathrm{ha}\end{array}$ & 80973 & 71398 & 72968 & 75113 & 115.7 & 76.2 & 92.0 & 94.6 & 14.6 & 10.4 & 12.9 & 12.63 \\
\hline $\begin{array}{l}\text { T9- Application of combination of micro nutrients as } \\
\text { formula - } 4 @ 2 \mathrm{~kg} / \mathrm{ha}\end{array}$ & 82079 & 56172 & 76388 & 71546 & 117.0 & 75.4 & 94.4 & 95.6 & 16.1 & 8.7 & 12.6 & 12.47 \\
\hline $\mathrm{CD}(0.05)$ & 2869.0 & 6314 & NS & & 8.35 & 8.6 & NS & - & - & - & - & - \\
\hline
\end{tabular}

The mean cane yield data indicated that irrespective of the type of micronutrient its application through drip fertigation increased the cane yield marginally over soil application. Application of combination of micro nutrients as Formula 4 (95.6 ha $\left.{ }^{-1}\right)$ or $\mathrm{FeSo}_{4} @ 25 \mathrm{~kg} / \mathrm{ha}$ through drip $\left(96.2 \mathrm{ha}^{-1}\right)$ registered higher cane yield than control $\left(84.4 \mathrm{ha}^{-1}\right)$ accounting for 14.0 and $13.3 \%$ yield increase over control respectively. Similar increase in cane yield with the application of Zinc and Boron @ $7.0-1.5 \mathrm{~kg} \mathrm{ha}^{-1}$ was reported by Shafique mazhar $(2016)^{[6]}$. 
Sugar yield followed similar trend as that of cane yield wherein higher sugar yield of $13.63 \mathrm{t} \mathrm{ha}^{-1}$ was obtained with the application of $\mathrm{FeSO}_{4} @ 25.0 \mathrm{~kg} \mathrm{ha}^{-1}$ through drip followed by $\mathrm{ZnSo}_{4}$ application@ $25 \mathrm{~kg} \mathrm{ha}^{-1}$ through drip (13.03 t/ha) compared to control (11.67 t/ha). Similar increase in sugar yield with the application of all micronutrients (zinc, iron and boron) was reported by Nagamadhuri et al., (2013).
Quality parameters: Quality of cane was assessed in terms of Brix, Sucrose and CCS\% at harvest and data are furnished in table 5. Mean data indicated that quality parameters were not significantly influenced by micronutrient application either alone or in combination as Formula 4. Brix values ranged from 19.89 to $21.1 \%$, sucrose \% ranged from 18.3 to 19.8 while CCS\% ranged from 12.9 to 14.4 in different treatments.

Table 5: Nutrient content and nutrient uptake at grand growth stage as influenced by micro nutrient application through drip fertigation

\begin{tabular}{|c|c|c|c|c|c|c|c|c|c|c|c|c|}
\hline \multirow[b]{2}{*}{ Treatments } & \multicolumn{6}{|c|}{ Nutrient content } & \multicolumn{6}{|c|}{ Nutrient uptake (Kg/ha) } \\
\hline & $\begin{array}{l}\text { Nitrog } \\
\text { en }(\%)\end{array}$ & $\begin{array}{c}\text { Phospho } \\
\text { rus (\%) }\end{array}$ & $\begin{array}{c}\text { Zinc } \\
(\mathbf{p p m})\end{array}$ & $\begin{array}{l}\text { Iron } \\
(\mathbf{p p m})\end{array}$ & $\begin{array}{c}\text { Copper } \\
(\text { ppm })\end{array}$ & $\begin{array}{c}\text { Manganes } \\
\text { e (ppm) }\end{array}$ & $\begin{array}{c}\text { Nitrog } \\
\text { en }\end{array}$ & $\begin{array}{c}\text { Phosp } \\
\text { horous }\end{array}$ & Zinc & Iron & $\begin{array}{l}\text { Cop } \\
\text { per }\end{array}$ & $\begin{array}{l}\text { Mang } \\
\text { anese }\end{array}$ \\
\hline T1: Control (With out micro nutrients) & 0.62 & 0.13 & 33 & 780 & 12 & 80 & 209.1 & 43.9 & 1.32 & 31.20 & 0.48 & 3.20 \\
\hline T2: Soil Application of $\mathrm{ZnSo}_{4} @ 50 \mathrm{Kg} / \mathrm{ha}$ & 0.60 & 0.13 & 31 & 800 & 14 & 81 & 223.4 & 48.4 & 1.28 & 33.07 & 0.58 & 3.35 \\
\hline T3: Application ofZnSo4 @ 25Kg /hathrough drip & 0.61 & 0.13 & 30 & 840 & 10 & 80 & 219.5 & 46.8 & 1.12 & 31.36 & 0.37 & 2.99 \\
\hline T4:Soil Application of $\mathrm{FeSo}_{4} @ 50 \mathrm{Kg} / \mathrm{ha}$ & 0.57 & 0.13 & 29 & 780 & 12 & 76 & 210.0 & 47.9 & 1.16 & 31.20 & 0.48 & 3.04 \\
\hline T5:Application ofFeSo4@ @25Kg /hathrough drip & 0.58 & 0.13 & 30 & 860 & 11 & 78 & 222.8 & 49.9 & 1.20 & 34.40 & 0.44 & 3.12 \\
\hline T6:Soil Application of B @ 1 Kg /ha & 0.61 & 0.12 & 31 & 820 & 13 & 81 & 230.6 & 45.3 & 1.28 & 33.89 & 0.54 & 3.35 \\
\hline T7:Application of B @ $0.5 \mathrm{Kg} /$ hathrough drip & 0.61 & 0.13 & 34 & 798 & 11 & 81 & 204.5 & 43.6 & 1.22 & 28.73 & 0.40 & 2.92 \\
\hline $\begin{array}{c}\text { T8- Soil application of combination of micro } \\
\text { nutrients as formula- } 4 \text { @ } 4.0 \mathrm{~kg} / \mathrm{ha}\end{array}$ & 0.59 & 0.13 & 32 & 820 & 12 & 80 & 223.5 & 49.2 & 1.28 & 32.80 & 0.48 & 3.20 \\
\hline $\begin{array}{l}\text { T9- Application of combination of micro nutrients } \\
\text { as formula }-4 @ 2 \mathrm{~kg} / \mathrm{ha}\end{array}$ & 0.60 & 0.13 & 31 & 830 & 15 & 84 & 236.5 & 51.3 & 1.28 & 34.31 & 0.62 & 3.47 \\
\hline
\end{tabular}

\section{Nutrient uptake}

Nutrient content of major and micro nutrients was estimated in whole plant samples at grand growth stage by following standard procedure and data are furnished in table 6. Nitrogen content in different treatments ranged from 0.58 to 0.62 , phosphorus content ranged between 0.12 to 0.13 while the micronutrients zinc, iron, copper and manganese ranged from 0.35 to $0.37,0.24$ to $0.25,0.29$ to 0.31 and 0.26 to 0.28 respectively. Nutrient uptake was arrived based on nutrient content and dry matter production at grand growth stage. A perusal of the data in table 6 revealed that uptake of major nutrients $(\mathrm{N} \& \mathrm{P})$ and micronutrients $(\mathrm{Zn}, \mathrm{Fe}, \mathrm{Cu}, \mathrm{Mn})$ was higher with the application of micronutrients mixture as Formula 4 compared to control. (Table 6).

\section{Acknowledgements}

The authors are highly grateful to the Acharya N.G.Ranga Agricultural University, Guntur for providing physical amenities and financial assistance for conduct of the experiment.

\section{References}

1. Gouri V, Bharathalakshmi M, Sitaramalakshmi $\mathrm{CH}$, Kumari MBGS, Ramana Murthy KV,Chitkala Devi T. Effect of micronutrient application through soil and drip fertigation on yield and quality of sugarcane. Proceedings of International Symposium on sugarcane research since Co 205: 100 years and beyond. Sucrosym, 2017, 500-502.

2. Gui-Fenchen, Qi-Zhan Tang, Yang - Rui Li, Yu - Yi Huang, Bin Liu, Lin Huet al.Effects of sub soil drip fertigation on sugarcane in field conditions. Sugar Tech.2012; 14(4):418-421.

3. Jamro GH, Kazi BR, Oad FC, Jamali NM, Oad NL. Effect of foliar application of micronutrients on the growth triats of sugarcane variety Cp-65/357 (Ratoon crop),2002.

4. Nagamadhuri KV, Sarala NV, Hemanth Kumar M, Subba Rao M, Giridhar V.Influence of micronutrients on yield and quality of sugarcane. Sugar Tech. 2013; 15(2):187191.
5. Panhwar RN, Keerio HJ, Memon YM, Junejo S, Arain MY, Chohan M et al. Response of Thatta - 10 Sugarcane variety to Soil and Foliar Application of Zinc Sulphate $\left(\mathrm{ZnSo}_{4} .7 \mathrm{H}_{2} \mathrm{O}\right)$ Under Half and Full Doses of NPK Fertilizer. Journal of Applied Sciences.2003; 3:266-269.

6. Panse V.G and Sukhatme P.V. Statistical methods for Agricultural workers. Indian council of Agricultural Research, New Delhi. 1986.

7. Shafique Mazhar.Impact of Zinc and Boron application on growth, cane yield and recovery in sugarcane, Life Sciences International Journal. 2016; 10(1):30-37. 